\title{
DO SPLEEN MACROPHAGE AGGREGATES UNDERGO SEASON-DEPENDENT CHANGES? A STEREOMICROSCOPIC INVESTIGATION IN WILD OHRID TROUT (SALMO LETNICA KAR.)
}

\author{
Katerina Rebok ${ }^{*}$, Irena Tavčiovska-Vasileva, Maja Jordanova \\ Institute of Biology, Faculty of Natural Sciences and Mathematics, Ss. Cyril and Methodius University, \\ Skopje, Republic of Macedonia \\ *Corresponding author, e-mail: katerinarebok@yahoo.com
}

\begin{abstract}
In past decades macrophage aggregates (MACs) were being used in many monitoring studies as useful immunological biomarkers of environmental pollution and they are still encountered in the so-called "future biomarkers", since quantitative studies in aquaculture and/or field of their normal fluctuations as a result of the influence of natural factors are extremely rare. Our investigation was designed to quantitatively evaluate the influence of the seasons on MAC's relative volume, number and diameter in the Ohrid trout (Salmo letnica Kar.) spleen. Data showed that all investigated parameters had significantly higher values in fish collected during spring and winter. Correlation analyses revealed that the increasing of the relative volume of MACs is a result of the increasing of the relative volume of melanin loaded MACs, as well as the increasing of their number and diameter. These results confirmed that the season can affect MACs variations and should be taken into consideration, especially when spleen MACs are used as pollution biomarkers in monitoring studies.
\end{abstract}

Keywords: spleen; macrophage aggregates; Ohrid trout; season

\section{INTRODUCTION}

The growing concern of today, the discharge of industrial, agricultural and domestic waste water into the environment [1], which results in the pollution of aquatic ecosystems, increased the trend for finding and establishing early-warning signals and biomarkers for evaluating or predicting the impact of chemicals in aquatic ecosystems. Macrophage aggregates (MACs), or also named melanomacrophage centers, over the past 40 years have been used in many monitoring programs as useful, nonspecific, anatomical and immunohystochemical biomarkers of environmental pollution [2, 3]. MACs represent focal accumulations of pigment-bearing cells which are a prominent feature in the stroma of the haemopoietic tissue in all teleosts, being found in the spleen, kidney and to a lesser extent in the liver [4].

In regard to their function, MACs collect pigments (hemosiderin, lipofuscin/ceroid and/or melanin), which is reflected in pathological processes and tissue destruction [5]. As a principal phagocytic cell in fish MACs may be multifunctional, ranging from acting as scavengers, involvement in bacterial killing, deposits for iron, to possible involvement in immuno-regulation. The ability of MACs to retain antigens for long periods, possibly in the form of immune-complexes, and eventually presenting them to immunocompetent cells, has drawn comparisons with germinal centres in higher vertebrates $[2,6]$.

Changes in the visceral MACs in fish appear to have the qualities needed for a relatively efficient health monitoring system [7]. Their value lies in their ubiquity, availability and ease of measurement. Variability in MACs number, size, relative amount and pigment content in relation to environmental contamination have been noted by a number of investigators as a potential biomarker [5, 7-11]. Although, the actual reason for these changes is still uncertain and debatable and thus many 
authors consider them as too nonspecific structures, according to Wolke [2], the MACs non-specificity may be of great value in terms of "first-cut" biological markers and this may well prove to be a deciding advantage. These cells non-specificity lies in the fact that beside toxical contamination, several natural factors may also affect MACs metrics, including fish age, size, nutritional imbalance and reproductive cycle $[4,5,7,8,12-18]$. This is the reason why MACs are still considered as so-called "future biomarkers", since quantitative studies (in aquaculture and/or field) on their normal fluctuations as a result of the influence of natural factors are extremely scarce.

To consider one structure, or one system as a biomarker of environmental pollution, its normal appearance or absence, as well as its range of variation in healthy organisms should be registered. It is already elaborated that MACs morphology, presence and range of fluctuations are organ and species specific [8]. In Salmoniformes and Clupeiformes, MACs are more difficult to be defined and consequently to be quantified, due to morphological differences with other teleosts. Considering the difficulties in defining and counting MACs, their usefulness in assessment of fish and environmental health is not confirmed yet in salmonids [19]. Moreover, utility of MACs changes in salmonids, as in all teleosts, as biomarkers must be based and supported on previously determined data of normal fluctuations of MACs metrics [17].

In this context, in order to contribute to basic data for normal MACs variations in the Ohrid trout (Salmo letnica Kar.) we addressed the question of season-dependent alterations of these cell clusters. In this regard, our investigation was designed to evaluate quantitatively (stereology) the influence of the seasons on MAC's relative volume in the spleen of wild adult females of the Ohrid trout. Moreover, we also investigated changes of the MAC's number and diameter to determine if their amount or size were seasonally dependant.

\section{MATHERIAL AND METHODS}

\section{Study area}

Ohrid Lake is the oldest lake in Europe, formed 4-10 milion years ago, and also the deepest lake in the Balkans with a maximum depth of 289 $\mathrm{m}$, and a mean depth of $164 \mathrm{~m}$. It is located between the southwestern part of the Republic of Macedonia and eastern Albania, at 41 degree north latitude and between 20 and 21 degrees east longitude, at an altitude of $695 \mathrm{~m}$ and covers an area of
$385.2 \mathrm{~km}^{2}$. Named as a "museum of living fossils", this lake represents a refuge for numerous freshwater organisms from the tertiary period, which makes it an unique aquatic ecosystem with more than 200 endemic species of worldwide importance. One of the endemic species, maybe not the most important, but the species throughout which this lake and our country is worldwide recognizable is the Ohrid trout.

\section{Fish collection}

Over the course of the investigation (from June 2000 till December 2001), adult female Ohrid trout fish were collected by legal and professional hatcheries. Sampling of the investigated trout was conducted in four seasons, with a random selection of specimens used in the study. The number of collected fish regarding the season was as follows: spring -7 , summer -16 , autumn -6 and winter -8 . All selected fish were held in vital condition, in suitable containers and with frequent replenishment of lake water until necropsies could be performed (not longer than one hour) in the ship-board laboratory.

\section{Necropsy procedure and tissue sampling}

Immediately after the catching all fishes were inspected externally for gross abnormalities and total length $(\mathrm{mm})$, fork length $(\mathrm{mm})$ and weight (g) were measured. The mean values for body weight (BW) in grams and total length (TL) in centimeters (standard deviation is given in brackets) for fish included in this study, divided by season, were as follows: spring BW: 870.00 (121.2), TL: 46.21 (2.9); summer BW: 763.75 (640.5), TL: 38.33 (8.1); autumn BW: 283.33 (74.2), TL: 30.43 (2.8); and winter BW: 1012.50 (317.3), TL: 46.34 (3.2). For estimating the condition factor as a biomarker of cumulative, organism-level changes the following formula was used: $\mathrm{CF}=\mathrm{BW} \times 100 / \mathrm{FL}^{3}$. Afterwards, fish were killed by rapid severance of the spinal cord just behind the opercula, dissected and inspected for abnormalities of the internal organs. In order to avoid autolysis of tissues, a sample from the middle part of the spleen was rapidly removed and fixed in 10\% formalin for histological assessment. For light microscopy (LM) analyses, tissue blocks were routinely dehydrated in series of alcohols, embedded in paraffin and cut into $5 \mu \mathrm{m}$ sections. SRS methods (systematic random sampling method) were used for selecting 5 sections from each tissue block for basic examination and were stained with haematoxylin and eosin (H\&E) method. Additionally, 1 section was separated and stained with Perl's method for determination of hemosiderin deposits in MACs. 


\section{Stereological approach}

All measured MACs metrics were obtained with classical stereological methods on LM. Point counting techniques [20] was used for determining the quantitative changes in the relative volume $\left(\mathrm{V}_{\mathrm{V}}\right)$ of the MACs. $\mathrm{V}_{\mathrm{V}}$ was measured for total MACs (MACs), and separately for melanin loaded MACs (mMACs) and hemosiderin loaded MACs (hMACs). From each section 20 fields were quantified (100 fields per fish) using the SRS method, with a final magnification of $400 \times$. After the point counting, $\mathrm{V}_{\mathrm{V}}$ (expressed as percentages) was calculated by the following formula:

$$
\begin{gathered}
\mathbf{V}_{\mathbf{V}}(\text { structure, reference })=\mathbf{V}_{\mathbf{V}}(\mathbf{s}, \mathbf{r}) \\
=[\mathbf{P}(\mathbf{s}) \times 100] \div \mathbf{P}(\mathbf{r}),
\end{gathered}
$$

where:

$\mathbf{V}_{\mathbf{V}}(\mathbf{s}, \mathbf{r})$ is the percentage of the total volume of a reference space occupied by one particular given structure within that space,

$\mathbf{P}(\mathbf{s})$ is the total number of test points lying over the reference space,

$\mathbf{P}(\mathbf{r})$ is the number of points falling over a chosen structural component.

The number of MACs in a $1 \mathrm{~mm}^{2}$ of tissue was estimated using an ocular with exactly defined space. 20 systematically selected field samples from each section (100 per fish) were quantified on a final magnification of $400 \times$. Concerning the diameter of MACs, micrometer scale was inserted into the ocular of the microscope with known dimension for the divisions and MAC's larger axis was measured on a final magnification $400 \times$. A diameter of at least 150 MACs per fish was estimated.

\section{Statistical analysis}

The data for all measured parameters is presented as group means from individual fish values, accompanied with the respective coefficients of variation $(\mathrm{CD}=\mathrm{SD} / \mathrm{Mean})$. Statistical comparisons were made using the software Statistica 7.0 for Windows. Differences among groups were evaluated by a one-way ANOVA, followed by the Newman-Keuls test, whenever ANOVA was significant for the effect under test. Correlation analyses were used to find specific linear associations between $V_{V}$ for all MACs and melanin loaded MACs, hemosiderin loaded MACs, as well as between $\mathrm{V}_{\mathrm{V}}$ and diameter and number of MACs, using the Spearman rank order correlation test. Differences were considered significant when $p<0.05$.

\section{RESULTS AND DISCUSSION}

The health status of the investigated Ohrid trout was recorded throughout the process of determination for presence of gross abnormalities and condition factor. Morphological inspection of the caught individuals preformed prior to histological assessment showed that all specimens were without any visual abnormalities in regard to external features or visceral organs examination. In the second gross health indices the CF revealed narrow variations, from 1.07 in fish collected in spring to 1.41 in fish collected in summer. Statistical analyses showed significant differences between CF from spring collected fish with CF from summer and autumn collected fish. These seasonal variations observed in the Ohrid trout could be result of seasonal changes in nutrient availability considering that $\mathrm{CF}$ is an index that reflects interactions between biotic and abiotic factors in the physiological condition of the fish [21], indicates the nutritional state of fish [1] and provides information for energy reserves [22]. However, a CF value between 0.8 and 1.2 indicates no deviation from the normal status, as stated by Bernet and Segner [23]. Therefore, calculated CF values in this study showed that although wildlife specimens were used, all investigated fish were in good condition.

Histological inspection of the spleen tissue of all examined fish used in this investigation showed presence of MACs in this organ. This revealed that MACs represent normal features within the spleen of the Ohrid trout. Scattered through the organ parenchyma, MACs were observed in both compartments (white and red pulp), usually concentrated around blood vessels. Qualitative observations revealed numerous, randomly positioned cell clusters, with irregular shape and different sizes (Fig, 1). These qualitative attributes are common for lower teleosts, an exception from higher bony fishes the Clupeiformes and the Salmoniformes [12, 13].

As pigment-bearing cells, MACs can contain melanin, lipofuscin/ceroid and hemosiderin into their cytoplasm separately, in a combination, or all of the pigments together in one cell. Hematoxylin and eosin stained spleen sections showed predominant presence of melanin pigment into the MACs with yellow to black coloration. Additional Perl's staining confirmed this observation revealing a rare appearance of MACs loaded with hemosiderin (Fig, 2 ), a pigment that appears bright blue coloured when this technique of staining is used. It is interesting that MACs in Ohrid trout spleen contained a low hemosiderin load, since it is well known that the distribution of hemosiderin is generally restricted to the spleen MACs and it is a normal feature 
both in fish and homeotherms $[7,13,14]$. Similar results are reported for chub, Leuciscus cephalus [24], where spleen MACs melanin was a dominant pigment. These studies are in accordance with the results from our investigation, revealing that MACs pigment composition is species specific or provoked by some exogenous factors. This requires additional investigations considering that some environmental factors such as water quality and certain type of contaminants could provoke changes in the MACs pigment composition $[8,25]$.

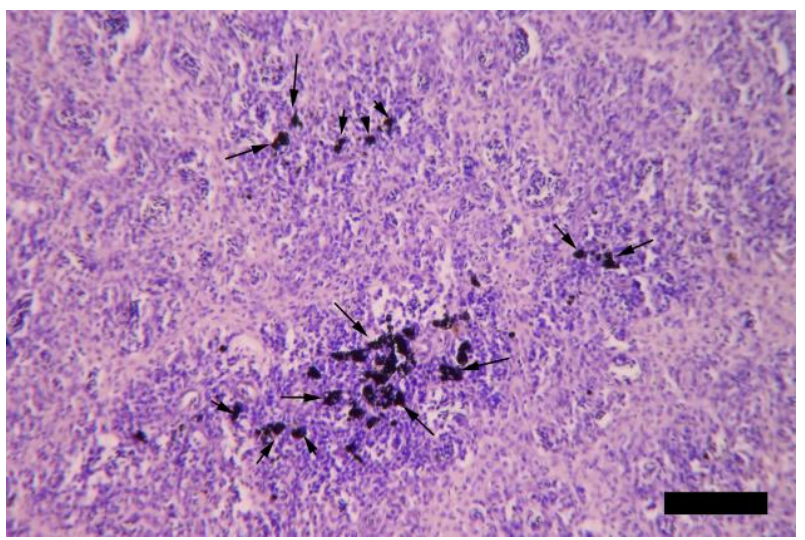

Figure 1. Light micrograph of the spleen from spring collected Ohrid trout. Numerous MACs (arrows) with different size are scattered through the parenchyma. MACs cytoplasm is coloured with brown-black (melanin) pigment. H\&E. Bar $=5 \mu \mathrm{m}$.

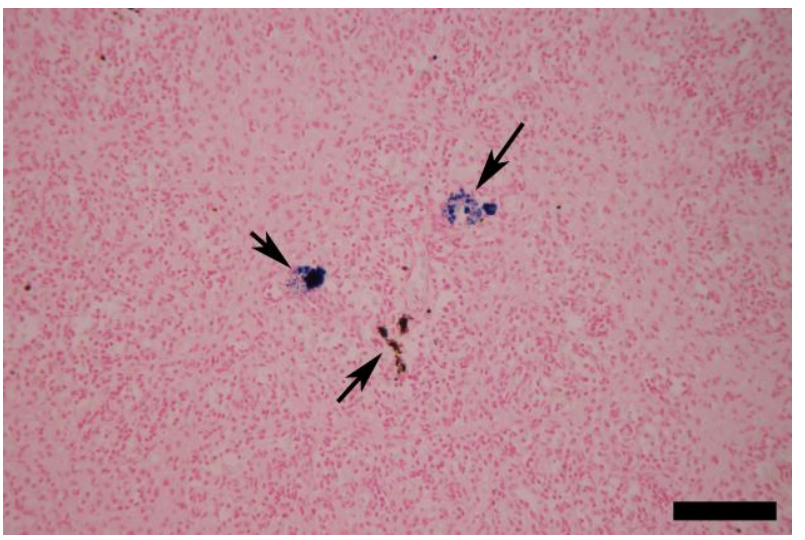

Figure 2. Light micrograph of the spleen from autumn collected Ohrid trout. Small amount of MACs (arrows) in the spleen tissue can be noted. They are loaded with melanin (brown-black colour) and hemosiderin (light blue colour) pigment. Perl's method. Bar $=10 \mu \mathrm{m}$.

Quantitative approach confirmed this qualitative evaluation. Namely, it is obvious that the relative volume of hemosiderin loaded MACs $\left[\mathrm{V}_{\mathrm{V}}(\mathrm{hMACs} /\right.$ spleen $\left.)\right]$ participated in small amounts of the relative volume of total MACs $\left[\mathrm{V}_{\mathrm{V}}(\mathrm{MACs} / \mathrm{spleen})\right]$ (Table 1). The majority of the relative volume of MACs was a result of the presence of MACs loaded with melanin pigment. Melanin deposits into the MACs are a more common feature in the aggregates of cold-water fish and fish kept at cold temperatures, rather than in warm-water fish, or in fish in colder periods of the year - autumn and winter [7, 26]. However, according to the results obtained in this study, in the splenic MACs of Ohrid trout melanin dominates in all four seasons. Similarly, in wild Gilthead sea bream (Sparus aurata) melanin was the most abundant pigment in hepatic, renal and spleen MACs throughout the year, but its amount was influenced by season [26]. In our research there are seasonal variations with statistically higher $\mathrm{V}_{\mathrm{V}}$ for total MACs and melanin loaded MACs in spring and winter (colder period of the year, with the temperature of the water $9.4^{\circ} \mathrm{C}$ and $8.4^{\circ} \mathrm{C}$, respectively) compared with summer and autumn (with the temperature of the water $20.6^{\circ} \mathrm{C}$ and $17.5^{\circ} \mathrm{C}$, respectively), while for $\mathrm{V}_{\mathrm{V}}$ of hemosiderin loaded MACs those fluctuations were not significant (Table 1). These variations in $\mathrm{V}_{\mathrm{V}}$ were accompanied with increased MACs diameter and number in the same seasons (Table 2). Correlation analyses revealed that the increasing of the $\mathrm{V}_{\mathrm{V}}$ of total MACs is a result of the increasing of the $\mathrm{V}_{\mathrm{V}}$ of melanin loaded MACs and not hemosiderin loaded MACs, and thereby the increasing volume occurs as a result of the increasing of the MACs diameter, in particular their number in the spleen parenchyma. Namely, significant positive correlation was evident between the $\mathrm{V}_{\mathrm{V}}$ of total MACs and their diameter, number and $\mathrm{V}_{\mathrm{V}}$ of melanin loaded MACs $(p<0.001$ for all). Moreover, the diameter and number of MACs positively correlate with each other $(p<0.001)$. Evenmore, MACs diameter revealed positive correlation with $\mathrm{V}_{\mathrm{V}}$ of total MACs $(p<0.001)$, melanin loaded MACs $(p<0.01)$ and hemosiderin loaded MACs $(p<0.001)$, while strong positive correlation was also observed between MACs number and $\mathrm{V}_{\mathrm{V}}$ of total MACs, melanin loaded MACs and hemosiderin loaded MACs $(\mathrm{p}<0.001$ for all).

These seasonal fluctuations could be attributed to fluctuations of water temperature. Namely, fish MACs are part of the non-specific immune system of the fish and are a first line of defence for the organism. Many parameters in the environment can have an effect on fish immunity, among which water temperature has been considered as the leading factor [27] which can provoke changes in the MACs metrics [5], especially in females [25]. As it was stated by Watts et al. [28], ambient temperatures lower than optimal for concrete species could provoke immunosuppression of both specific and nonspecific immune responses, but temperature effects are less characterized for the last one. 
Table 1. The relative volume ${ }^{1}$ of the total, melanin loaded (mMACs) and hemosiderin loaded (hMACs) MACs in the spleen of Ohrid trout females

\begin{tabular}{lccc}
\hline Season & {$\left[\mathbf{V}_{\mathbf{V}}(\mathbf{M A C s} / \mathbf{s p l e e n})\right](\%)$} & {$\left[\mathbf{V}_{\mathbf{V}}(\mathbf{m M A C s} / \mathbf{s p l e e n})\right](\%)$} & {$\left[\mathbf{V}_{\mathbf{V}}(\mathbf{h M A C s} / \mathbf{s p l e e n})\right](\%)$} \\
\hline Spring & $2,67(0,37)^{\mathrm{a}}$ & $2,51(0,42)^{\mathrm{a}}$ & $0,16(0,78)$ \\
Summer & $1,33(0,71)^{\mathrm{b}}$ & $1,30(0,74)^{\mathrm{b}}$ & $0,04(1,60)$ \\
Autumn & $0,88(0,58)^{\mathrm{b}}$ & $0,77(0,53)^{\mathrm{b}}$ & $0,11(2,18)$ \\
Winter & $2,40(0,34)^{\mathrm{a}}$ & $2,30(0,34)^{\mathrm{a}}$ & $0,10(0,78)$ \\
\hline
\end{tabular}

${ }^{1}$ Values are expressed as mean (coefficient of variation).

${ }^{\mathrm{a}, \mathrm{b}}$ For every metric, the values assigned with different letters ( $\mathrm{a}$ or b) statistically significant differ from one another; the values assigned with the same letter do not differ from one another (read vertically); while the metric where no letter is assigned revealed no statistical differences, according to the ANOVA followed by Newman-Keuls test.

Table 2. The diameter and number of MACs in $\mathrm{mm}^{2}$ in the spleen of Ohrid trout females ${ }^{1}$

\begin{tabular}{lcc}
\hline Season & $\mathbf{d}(\boldsymbol{\mu m})$ & $\mathbf{N o} / \mathbf{m m}^{\mathbf{2}}$ \\
\hline Spring & $13,12(0,06)^{\mathrm{a}}$ & $108,86(0,31)^{\mathrm{a}}$ \\
Summer & $11,18(0,10)^{\mathrm{b}}$ & $60,50(0,54)^{\mathrm{b}}$ \\
Autumn & $10,16(0,09)^{\mathrm{b}}$ & $44,86(0,37)^{\mathrm{b}}$ \\
Winter & $14,26(0,23)^{\mathrm{a}}$ & $107,03(0,33)^{\mathrm{a}}$ \\
\hline
\end{tabular}

${ }^{1}$ Values are expressed as mean (coefficient of variation).

${ }^{\mathrm{a}, \mathrm{b}}$ For every metric, the values assigned with different letters (a or b) statistically significant differ from one another; the values assigned with the same letter do not differ from one another (read vertically), according to the ANOVA followed by Newman-Keuls test.

Non-specific immunity is vitally important during the whole life cycle in fish, it comes into play at times when the specific immune response is suppressed [29]. In vitro investigation of the phagocytic process in blood granulocytes in Tinca tinca, exposed on seasonal temperature fluctuations, revealed that different stages of the phagocytic process had the highest activity during winter and spring. This showed that phagocytosis in fish is more resistant to low temperatures than specific immune functions [30]. Those investigations make the assumption that in winter and in spring the specific immune response in Ohrid trout is limited, reinforcing the phagocytic non-specific immunity and resulting with increased values for the MACs relative volume, diameter and number.

In addition, this period of the year is characterized with lower nutrient availability due to lower water temperature. Starvation-induced increase in the degree of MACs deposition in different visceral organs, especially the spleen was noted in Pleuronectes plalessa, Salmo gairdneri, Xiphophorus helleri, Tilapia zillii, as well as in Scyliorhinus canicula [31], Cyprinus carpio [15], wild and hatchery-reared Oncorhynchus masou [32], Paralichthys olivaceus [33] and in $n-3$ highly unsaturated fatty acid (HUFA) deficiencies in Sparus aurata juveniles [16]. Nevertheless, the season as a natural factor is far more complex than the influence of only the two factors mention above. Changes in environmental factors (with ambient temperature, photoperiod and food access as the most outstanding cues) throughout the year determine the season; this could have an influence on animal physiology and could provoke variations in the immune parameters [34]. Even more, not only exogenous but also endogenous factors could have an influence on MACs variability, which could also have seasonal fluctuations, such as sexual endogenous status [17].

The previous investigation on the Ohrid trout, more concretely studies performed on the same individuals used in this study but in different organs (liver and kidney), revealed breedingdependent changes in MACs metrics [17, 18]. Namely, maximal values for the $\mathrm{V}_{\mathrm{V}}$ of MACs in the liver tissue were observed in the postspawning period [17], and in late vitellogenesis in kidney tissue [18]. It is interesting that for the investigated Ohrid trout, the postspawning period took place during the spring months, while late vitellogenesis during the end of autumn and the beginning of winter. Considering that maximal values for all investigated MACs parameters in the spleen were noted in spring and winter, it seems that spleen MACs coincide, at least in part, with MACs fluctuations in both liver and kidney. It was already assumed that MACs in fish had different physiological roles in different organs [14], so the observed mismatched pattern of variations in the MACs metrics into the three organs of Ohrid trout, beside seasonal fluctuations (with the highest values observed in cold period of the year for all of them), could also be attributed to an organ-specific effects.

In conclusion, in this study for the first time the normal variations of several MACs metrics (relative volume, diameter and number) in spleen tissue of healthy Ohrid trout were determined. Our results confirmed that beside other natural factors, 
the season could affect MACs variations. At the fish organism level, MACs respond to both physiological (endogenous) and environmental (exogenous) stimuli, making these indicators useful in a monitoring study. But as we stated before, the normal range of variations in healthy fish should be known prior to utilization of the MACs metrics in monitoring studies as biomarkers of pollution. Moreover reproduction/seasonal organ specific MACs response can complicate data interpretation and must be also taken into consideration. Study for MACs as potential immune system biomarker, although quite general, are needed to fully understand the relationship of these cells with endogenous as well as exogenous factors.

\section{REFERENCES}

[1] R. van der Oost, J. Beyer, N. P. E. Vermeulen, Fish bioaccumulation and biomarkers in environmental risk assessment: A review, Environ. Toxicol. Pharmacol., 13:2 (2003), pp. 57-149.

[2] R. E. Wolke, Piscine macrophage aggregates: A review, Annu. Rev. Fish Dis. (1992), pp. 91-108.

[3] D. E. Facey, V. S. Blazer, M. M. Gasper, C. L. Turcotte, Using fish biomarkers to monitor improvements in environmental quality, J. Aquat. Anim. Health., 17 (2005), pp. 263-266.

[4] C. Agius, R. J. Roberts, Melano-macrophage centers and their role in fish pathology, J. Fish Dis., 26 (2003), pp. 499-509.

[5] V. S. Blazer, R. E. Wolke, J. Brown, C. A. Powell, Piscine macrophage aggregate parameters as health monitors: effect of age, sex, relative weight, season and quality in largemouth bass (Micropterus salmoides), Aquat. Toxicol., 10 (1987), pp. 199-215.

[6] F. A. Vigliano, R. Bermúdez, Ma. I. Quiroga, J. M. Nieto, Evidence for melano-macrophage centres of teleost as evolutionary precursors of germinal centres of higher vertebrates: An immunohistochemical study, Fish Shell. Immunol., 21 (2006), pp. 467-471.

[7] R. E. Wolke, C. J. George, V. S. Blazer, Pigmented macrophage accumulations (MMC, PMB): Possible monitors of fish health, in: Parasitology and Pathology of Marine Organisms of the World Ocean, W. J. Hargis Jr. (Eds), NOAA Tech. Rep. NMFS 25, 1985, pp. 93-97.

[8] V. S. Blazer, D. E. Facey, J. W. Fournie, L. A. Courtney, J. K. Summers, Macrophage aggregates as indicators of environmental stress, in: Modulators of Fish Immune Responses: Volume 1, Models for Environmental Toxicology, Biomarkers, Immunostimulators, J. S. Stolen, T. C. Fletcher, D. P. Anderson, J. T. Zelikoff, L. E. Twerdok, S. L. Kaattari, C. C. Bayne (Eds), SOS Publications, Fair Haven, New Jersey, 1994, pp. 169-185.
[9] T. Meinelt, R. Krüger, M. Pietrock, R. Osten, C. Steinberg, Mercury pollution and macrophage centres in pike (Esox lucius) Tissues, Environ. Sci. Pollut. Res., 4:1 (1997), pp. 32-36.

[10] D. E. Facey, C. Leclerc, D. Dunbar, D. Arruda, V. S. Blazer, Physiological indicators of stress among fishes exposed to contaminated sediments from Lake Champlain, in: Stress in Fish, T. Barry, B. Barton, D. MacKinlay (Eds), International Congress on the Biology of Fish, Towson University, Baltimore, MD, 1998, pp. 83-88.

[11] J. W. Fournie, J. K. Summers, L. A. Courtney, V. D. Engle, V. S. Blazer, Utility of splenic macrophage aggregates as an indicator of fish exposure to degraded environment, J. Aquat. Anim. Health., 13:2 (2001), pp. 105-116.

[12] R. Roberts, Melanin-containing cells of teleost fish and their relation to disease, in: The Pathology of Fishes, E. Ribelin, G. Migaki (Eds), The University of Wisconsin Press, 1975, pp. 399-441.

[13] C. Agius, The role of melano-macrophage centres in iron storage in normal and diseased fish, J. Fish Dis., 2 (1979), pp. 337-343.

[14] C. Agius, The melano-macrophage centres of fish: A rewiew, in: Fish Immunology, M. J. Manning, M. F. Tatner (Eds), Academic Press, London, 1985, pp. 85-105.

[15] N. K. El-Fiky, Effect of starvation on the melanomacrophage centres of carp, Cyprinus carpio, J. Egypt. Ger. Soc. Zool., 27:B (1998), pp. 35-44.

[16] D. Montero, V. S. Blazer, J. Socorro, M. S. Izquierdo, L. Tort, Dietary and culture influences on macrophage aggregate parameters in gilthead seabream (Sparus aurata) juveniles, Aquaculture, 179 (1999), pp. 523-534.

[17] M. Jordanova, N. Miteva, E. Rocha, A qualitative and quantitative study of the hepatic pigmented macrophage aggregates during the breeding cycle of Ohrid trout, Salmo letnica Kar. (Teloestei, Salmonidae), Microscopy Res. Tech., 830 (2008), pp. 822-830.

[18] M. Jordanova, M. Rocha, K. Rebok, E. Rocha, Changes in the amount of kidney pigmented macrophage aggregates throughout the breeding cycle of female Ohrid trout, Salmo letnica Kar. (Teleostei, Salmonidae), Microsc. Res. Tech., 75:2 (2012), pp. 176-181.

[19] A. R. Schwindt, N. Truelove, C. B. Schreck, J. W. Fournie, D. H. Landers, M. L. Kent, Quantitative evaluation of macrophage aggregates in brook trout Salvelinus fontinalis and rainbow trout $\mathrm{On}$ corhynchus mykiss, Dis. Aquat. Org., 68 (2006), pp. 101-113.

[20] H. Freere, E. R. Weibel, Stereologic techniques in microscopy, J. R. Microsc. Soc., 87 (1967), pp. 25-34.

[21] B. K. Gupta, U. K. Sarkar, S. K. Bhardwaj, A. Pal, Condition factor, length-weight and length-length relationships of an endangered fish Ompok pabda 
(Hamilton 1822) (Siluriformes: Siluridae) from the River Gomti, a tributary of the River Ganga, India, J. Appl. Ichthyol., 27 (2011), pp. 962-964.

[22] F. L. Mayer, D. J. Versteeg, M. J. McKee, L. C. Folmar, R. L. Graney, D. C. McCume, B. A. Rattner, Metabolic products as biomarkers, in: Biomarkers: Biochemical, Physiological and Histological Markers of Anthropogenic Stress, R. J. Huggett, R. A. Kimerly, P. M. Mehrle, H. L. Bergman (Eds), Lewis Publishers, Chelsea, MI, 1992, pp. 5-86.

[23] D. Bernet, H. Segner, Effektstudie: Zusammenstellung von Fischgesundheitsdaten in der Schweiz, in: Fischnetz-Publikation. Teilprojekt $01 / 19$. Zentrum für Fisch- und Wildtiermedizin, Universität Bern und EAWAG, Bern / Dübendorf, (2004).

[24] A. S. Holzer, O. Schachner, Myxosporidia and macrophage centers in chub (Leuciscus cephalus) - quantitative interactions focus on Myxobolus cyprini, Parasitology, 122 (2001), pp. 55-62.

[25] R. Krüger, M. Pietrock, T. Meinelt, T. Yoshida, W. Steffens, Ch. Steinberg, Distribution of macrophage centres in bream (Abramis brama L.) liver from the Oder River (Germany/Poland) within the nature reserve "Unteres Odertal" near the town of Schwedt, Int. Revue ges. Hydrobiol., 81 (1996), pp. 635-644.

[26] M. Manera, R. Serra, G. Isani, E. Carpené, Macrophage aggregates in gilthead sea bream fed copper, iron and zinc enriched diets, J. Fish Biol., 57 (2000), pp. 457-465.

[27] M. Sakthivel, B. Deivasigamani, S. Kumaran, S. Balamurugan, T. Rajasekar, Seasonal variation in immune organs and immune response of catfish Arius maculatus in Parangipettai coastal area, $J$. Chem. Pharm. Res., 4:7 (2012), pp. 3342-3348.

[28] M. Watts, B. L. Munday, C. M. Burke, Immune responses of teleost fish, Aust. Vet. J., 79:8 (2001), pp. 570-574.

[29] M. Tatner, Natural changes in the immune system of fish, in: The Fish Immune System: Organism, Pathogen and Environment, G. K. Iwama, T. Nakanishi (Eds), Academic Press, Inc., San Diego, California, USA, 1985, pp. 255-288.

[30] M. E. Collazos, C. Barriga, E. Ortega, Seasonal variations in the immune system of the tench, Tinca tinca. Phagocytic function, Comp. Immunol. Microbiol. Infect. Dis., 18 (1995), pp. 105-113.

[31] C. Agius, R. J. Roberts, Effects of starvation on the melano-macrophage centres of fish, J. Fish Biol., 19 (1981), pp. 161-169.

[32] S. Mizuno, N. Misaka, Y. Miyakoshi, K. Takeuchi, N. Kasahara, Effects of starvation on melano-macrophages in the kidney of masu salmon (Oncorhynchus masou), Aquaculture, 209 (2002), pp. 247-255.

[33] J. W. Hur, S. R. Woo, J. H. Jo, I. S. Park, Effects of starvation on kidney melano-macrophage centre in olive flounder, Paralichthys olivaceus (Temminck and Schlegel), Aquaculture Res., 37 (2006), pp. 821-825.

[34] M. K. Tripathi, R. Singh, Seasonal variation and innate immune responses of spleen in fresh-water snake, Natrix piscator, J. Stress Physiol. Biochem., 10:1 (2014), pp. 292-300.

\title{
ДАЛИ МАКРОФАГНИТЕ АГРЕГАТИ ВО СЛЕЗИНАТА ПРЕТРПУВААТ СЕЗОНСКИ- ЗАВИСНИ ПРОМЕНИ? СТЕРЕОМИКРОСКОПСКИ ИСТРАЖУВАЮА КАЈ ДИВА ПОПУЛАЦИЈА НА ОХРИДСКАТА ПАСТРМКА (SALMO LETNICA KAR.)
}

\author{
Катерина Ребок, Ирена Тавчиовска-Василева, Маја Јорданова
}

\author{
Институт за биологија, Природно-математички факултет, Универзитет „Св Кирил и Методиј“, \\ Скопје, Република Македонија
}

\begin{abstract}
Во последните децении макрофагните агрегати (MACs) се користат во многу мониторинг-програми како корисни имунолошки биомаркери на загадувањето на животната средина, но сѐ уште се вбројуваат во таканаречените „идни биомаркери“, бидејќи квантитативните истражувања (во аквакултура и/или природни услови) на нивните нормални варирања кои се резултат на влијанието на природните фактори се екстремно ретки. Нашите истражувања беа извршени со цел да се определи влијанието на сезоната врз релативниот волумен, бројот и дијаметарот на МАCs во слезината на охридската пастрмка (Salmo letnica Kar.). Резултатите покажаа дека сите истражувани параметри имаат значително повисоки вредности кај единките колекционирани во пролет и во зима. Корелациските анализи покажаа дека зголемувањето на релативниот волумен на MACs е резултат на зголемувањето на релативниот волумен на MACs богати со меланин, како и зголемувањето на нивниот број и дијаметар. Овие резултати потврдија дека сезоната може да влијае врз варирањата на MACs и дека треба да биде земена предвид, посебно доколку МАСs од слезината се користат како биоиндикатори на загадување во мониторинг-студиите.
\end{abstract}

Клучни зборови: слезина; макрофагни агрегати; охридска пастрмка; сезона 
